\title{
LAND CAPABILITY EVALUATION FOR ECOTOURISM DEVELOPMENT IN ILAM PROVINCE, A GIS APPROACH
}

Avaliação da capacidade da terra para desenvolvimento de ecoturismo na província de Ilam, uma abordagem com utilização de SIG

\author{
MEHDI AHMADI*1 \\ SHAMSOLLAH ASGARI ${ }^{2}$ \\ EZATOLLAH GHANAVATI ${ }^{3}$
}

${ }^{1}$ Department of Geomorphology, Faculty of Geography, Kharazmi University, Tehran, Iran

${ }^{2}$ Scientific Member of Agriculture and Natural Resources Reserch Center of Ilam Provience, Iran

${ }^{3}$ Department of Geomorphology, Faculty of Geography, Kharazmi University, Tehran, Iran

*Corresponding Author: Mehdi Ahmadi; Email: mehdi.ahmadi2009@gmail.com; Cell Phone: +989189405535

\begin{abstract}
As one of the most wealth-generating industries in the world, tourism has been the center of attention by many governments worldwide. Depending on the purpose of tourism, it has been classified into different types, one of which is ecotourism. Given that ecotourism currently accounts for a small part of the whole, however, it has a rapid growth rate. The present study aims at zoning suitable areas in Ilam, a province in western Iran, for ecotourism development purposes. Accordingly, the digital maps of elevation, slope, land cover/land use, mineral springs, and water resources were prepared, at first. Afterwards, the suitable and unsuitable areas were segregated by Boolean functions. Overlaying the map layers by GIS software, the suitable areas were identified. The obtained results revealed that the top attractions are mainly distributed from the northern and central province to the southeastern parts where climatic condition is favorable, and rich in natural land cover and water resources. Moreover, the southern and western parts were evaluated poor in term of eco-tourist attractions.
\end{abstract}


Keywords: Land Capability Evaluation; Ecotourism Development; Boolean Algebra; Ilam Province (Iran); Geographic Information System; Remote Sensing.

\section{RESUMO}

Como uma das indústrias mais geradoras de riqueza no mundo, o turismo tem sido o centro das atenções de muitos governos em todo o mundo. Dependendo da finalidade do turismo, ele foi classificado em diferentes tipos, um dos quais é o ecoturismo. O ecoturismo é responsável atualmente por uma pequena parcela das receitas; no entanto, tem uma alta taxa de crescimento. $O$ presente estudo de caso visa ao zoneamento de áreas adequadas em Ilam, uma província no oeste do Irã, para fins de desenvolvimento do ecoturismo. Assim, foram elaborados inicialmente os mapas digitais de altitude, declividade, cobertura vegetal, uso do solo, nascentes de água mineral e de recursos hídricos. Depois, as áreas adequadas e inadequadas foram separadas por funções booleanas. A sobreposição das camadas através de um GIS permitiu identificar as áreas mais adequadas. Os resultados obtidos revelaram que as principais atrações estão localizadas, principalmente, nas província do norte e central, em direção sudeste, regiões em que a condição climática é favorável, e são ricas em recursos naturais de cobertura do solo e de água. Além disso, as regiões sul e oeste foram avaliados como pobres em termos de atrações eco-turísticas.

Palavras-chave: Avaliação da Aptidão das Terras; Desenvolvimento do Ecoturismo; Álgebra Booleana; Província de Ilam (Irã); Sistema de Informação Geográfica; Sensoriamento Remoto.

\section{INTRODUCTION}

Tourism development as an economic activity has a significant impact on empowering local communities. The role of tourism, as a new source of job creation, revenues, taxes, and currencies, has been taken into consideration by numerous studies (Howard, 2009).

Nowadays, the development of tourism is widely accepted and placed on the agenda by developing and developed countries (Stueve, 2002). Tourism leads money and population from industrial centers towards natural and rural areas. The revenue from tourism contributes to the economy and social welfare of the host country (Cater, 1994). According to World Tourism Organization (WTO), ecotourism proportion will reach from the current of $7 \%$ to $20 \%$ in the coming decade (Ross, 1980).

Although tourism development may cause loss of native language and local culture (Miller, 2001), it can cause the development of the host countries in terms of educational and cultural conditions (Brandon, 2001). Therefore, sustainable ecotourism is one aspect consistent with the nature(Hunter, 1997). Ecotourism is considered as a part of sustainable tourism (Ceballos- Lascurain, 1993; Wells, 1992). Providing opportunities for employment of services provided by locals and 
giving natural unspoilt areas an economic value are the most important benefits of ecotourism (Alpert, 1996).

It can also create benefits for local people and attract international support for protected areas (Fennel, 1999). Hence, the support and participation of local people is essential to achieve sustainable ecotourism (Yoon, 2001). Ecotourism development should increase the maximum local participation in conservation of natural areas (Cooke, 1982).

The correct diagnosis of tourist behavior will contribute to suitable site selection of tourist destinations (Bansal, 2004). Ecotourism is defined as responsible travel to nature where the flora, fauna, and cultural heritage are the primary attractions in a way to conserve the environment and improves the well-being of local people (Boo, 1990). Due to great income generation, tourism and ecotourism have urged countries to pay special attention to this industry (Tremblay, 2006). This form of tourism is based on purposeful travel coupled with cultural and spiritual understandings of a variety of natural phenomena (Choong, 2008). Ecotourism means traveling to different parts of countries to visit natural monuments and get more familiar with different cultures.

Given the mentioned circumstances, what is important in this type of tourism is the issue of sustainability (Honey, 2008). Valuation of ecosystem services and natural environment is very important for sustainable tourism management. There has been a wide range of approaches and methods presented in recent years to evaluate ecosystem values (Eade and Moran, 1996; Guo et al., 2001; Hein et al., 2006; Troy and Wilson, 2006; Egoh et al., 2008). According to literature, CeballosLascurain (1993) is the one who first used the concept of ecotourism. He defined it as "a form of environmentally responsible tourism that involves travel and visitation to relatively undisturbed natural areas with the object of enjoying, admiring, and studying the nature (the scenery, wild plants, and animals), as well as any cultural aspect (both past and present) found in these areas, through a process which promotes conservation, has a low impact on the environment and on culture and favors the active and socioeconomically beneficial involvement of local communities".

Banerjee et al. (2002) identified potential ecotourism sites in eastern India using Remote Sensing (RS) and GIS techniques in forest dominated areas of western Midnapore, West Bengal. They prepared the final ecotourism capability map by overlaying the map layers of land use/land cover, soil fertility, and ecological features.

Bukenya et al. (2002) applied GIS to zone Uganda National Park (Bukenya, 2002). Dondo et al. (2003) performed a research entitled "GIS in tourism - A Zimbabwean perspective, the international archives of photogrammetry" to specify situation of the resort areas to the visitors. Changa et al. (2007) used the maps of topography, land cover/land use, and human resources to identify suitable areas for ecotourism developement (Changa, 2007). 
In a study by Elliott-White in 1997, the application of GIS in post-modern tourism marketing was investigated. Further, the role of GIS in tourism planning and rural economic development was studied by Savitsky et al. in 1999. The researches by Lee and Mjelde in 2012, Sanjay in 2007, Lung Shaw in 2007, and Baral in 2007 are other examples of feasibility studies for ecotourism development. Turner et al. in 1995 and Laughland et al. in 1996 mainly focused on the role of ecosystem services in ecotourism blooming.

There are some relevant research projects conducted by Department of Environment of Ilam Province on ecotourism developement. As such, the historic buildings of Ilam by Heidari et al. in 2003, investigation of tourism building in Ilam by Johari in 2005, and land capability evaluation of Ilam are among notable research projects that could be mentioned (Jafree, 2003). Although Iran is ranked $10^{\text {th }}$ in the world in terms of tourist attractions and $5^{\text {th }}$ in the world in view of Earth's greatest biological diversity, however, it has failed to take a proper position in the world in attracting tourists. The share of tourism revenues in Iran is about a thousandth of the global income (Amami, 2000). Despite having many attractions, there have been done no scientific feasibility studies on introducing and analyzing potential sites for ecotourism developement. Accordingly, the present study was conducted to introduce ecotourism values of the Ilam Province. The obtained results could be used by tourists and planners.

\section{MATERIAL AND METHODS}

\subsection{The study area}

The Ilam Province, with an area of about $20,150 \mathrm{~m}^{2}$, includes approximately $1.4 \%$ of the total area of Iran. It is situated in western and southwestern Iran between the latitudes $31^{\circ} 58^{\prime}-34^{\circ} 15^{\prime} \mathrm{N}$ and the longitude $45^{\circ} 24^{\prime}-48^{\circ} 10^{\prime} \mathrm{E}$ (Encyclopedia of Ilam City, 2008) (Figure 1).

Figure 1- Situation of the Ilam Province in Iran

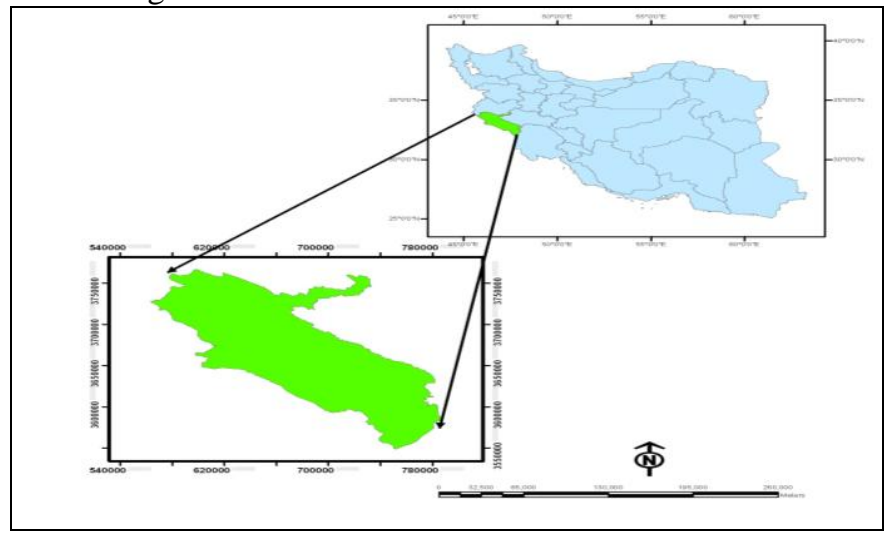

Bol. Ciênc. Geod., sec. Artigos, Curitiba, v. 21, nº 1, p.107-125, jan-mar, 2015. 


\subsection{Boolean Logic Model}

In overlaying function, the Boolean logic operations are based on Boolean algebra in which the values of the variables are the truth values true and false. First used by Varennes in 1947, the Boolean model is a multi-conditional inquiry by which suitability maps could be presented as 0 and 1 subsets (Olazade, 2005). This model has a two-element set of suitability and unsuitability and there is no other state in the middle (Sanaei Nejad, 1999).

\subsection{Data collection and processing}

In order to evaluate ecological capability of Ilam Province, the maps of land cover, slope, land use, and hydrology were used. The topographic map of the study area at the scale of 1:50,000 was used to extract some geomorphological features including faults, ridges, and elevation points. The slope map was extracted from the Digital Elevation Model (DEM) to specify areas with the slope of higher than 20\%, which are suitable for rock climbing, hiking in steep terrain, mountaineering, and hillside climbing. The Indian Remote Sensing (IRS) LISS-III (Linear Imaging Self Scanning Sensor) sensor (with the spatial resolution of $23 \times 23 \mathrm{~m}$ ) and $\mathrm{ETM}^{+}$satellite images were prepared from the Geographical Organization of Iran in order extract land use and land cover map of the study area using ERDAS IMAGINE Software. It is worth mentioning that LISS-III sensor is an optical sensor working in four spectral bands of green, red, near infrared, and short wave infrared. It covers a 141 $\mathrm{km}$-wide swath with a resolution of 23 metres in all spectral bands. The current land use map was obtained from the landsat satellite images dating to 2002. The isothermal map of the province was used to zone suitable temperature areas and to identify places with low temperature for winter activities such as skiing. Moreover, the slope and hillshade maps were used to identify the accumulation places of snow and ice as an important prerequisite for establishment of ski resort. It is worth noting that the mentioned maps were all prepared from the DEM. The drainage network map of the province at the scale of 1:250,000 was prepared from the Department of Environment (DOE). The map of fragile habitats and protected areas was obtained from Administration of Environmental Protection in Ilam Province. The data was used for zoning authorized hunting and fishing areas. The map of historic attractions was prepared based on the comprehensive plan for feasibility study of typical tourism resorts conducted by Cultural Heritage Department of Ilam Province. These areas were represented as a point map taken by GPS from the study area.

\subsection{Data processnig}

After preparing all the required map layers, they were converted from vector into the raster format. After importing into the GIS, the map layers were scrutinized and converted into a unique coordinate system and the same cell size in order to make them standardized. Based on the DEM of the study area, the cell size was 90x90m. The data coordinate system was WGS84, Zone 38N. In Boolean logic, the units of each map layer are weighted based on the zero and one logic. In other 
words, each cell size of the final map is suitable or unsuitable for ecotourism development and there is no intermediate state. The logic is involved in two numbers; 0 and 1 , of which 1 represents suitability of a pixel size, while 0 shows unacceptable situation or unsuitability of a pixel size (Hall et al,1992). Tables 1 and 2 give the functions applied for overlaying each of the map layers. After weighting the map layers, the final ecotourism development map was prepared using Boolean logic. The spatial distribution of suitable tourism resorts are specified are presented on the final map.

Table 1- Map layers used for Boolean-based ecotourism land capability evaluation (Faraj Zadeh, 2008)

\begin{tabular}{|c|c|c|c|c|c|c|c|c|c|}
\hline \multirow[b]{2}{*}{ No. } & \multirow[b]{2}{*}{$\begin{array}{l}\text { Map } \\
\text { layers }\end{array}$} & \multicolumn{8}{|c|}{ Type of tourist activity } \\
\hline & & $\begin{array}{c}\text { Mountain } \\
\text { neering }\end{array}$ & $\begin{array}{l}\text { Hill } \\
\text { side } \\
\text { clim- } \\
\text { bing }\end{array}$ & $\begin{array}{l}\text { Hiking- } \\
\text { insteep } \\
\text { terrain }\end{array}$ & $\begin{array}{c}\text { Skiing } \\
\text { and } \\
\text { other } \\
\text { winter } \\
\text { sports }\end{array}$ & $\begin{array}{l}\text { Water } \\
\text { sports } \\
\text { and } \\
\text { fishing }\end{array}$ & $\begin{array}{l}\text { Eco- } \\
\text { tourism }\end{array}$ & $\begin{array}{l}\text { Hun- } \\
\text { ting }\end{array}$ & $\begin{array}{c}\text { Visi- } \\
\text { ting } \\
\text { histo- } \\
\text { rical } \\
\text { monu- } \\
\text { ments }\end{array}$ \\
\hline 1 & Elevation & $*$ & $*$ & - & $*$ & - & & & \\
\hline 2 & Slope & $*$ & $*$ & - & $*$ & - & & & \\
\hline 3 & $\begin{array}{l}\text { Land } \\
\text { cover }\end{array}$ & - & * & - & - & - & * & & \\
\hline 4 & $\begin{array}{l}\text { Aquatic } \\
\text { surfaces }\end{array}$ & - & $*$ & - & - & * & $*$ & & \\
\hline 5 & Rivers & $\ldots$ & $*$ & $*$ & - & $*$ & $*$ & & \\
\hline 6 & $\begin{array}{l}\text { Mineral } \\
\text { springs }\end{array}$ & - & - & $*$ & - & $*$ & - & & \\
\hline 7 & Geology & - & $*$ & - & - & - & * & & \\
\hline 8 & $\begin{array}{c}\text { Land } \\
\text { suitability }\end{array}$ & $*$ & $*$ & & & & $*$ & & \\
\hline 11 & isothermal & & & & $*$ & $*$ & $*$ & & \\
\hline 12 & Isohyethal & & $*$ & & $*$ & $*$ & & & \\
\hline 14 & $\begin{array}{c}\text { Historic } \\
\text { affractions }\end{array}$ & & & & & & & & * \\
\hline 15 & Habitats & & & & & & & $*$ & \\
\hline
\end{tabular}


Table 2- Applied functions for overlaying of the map layers (Faraj Zadeh, 2008)

\begin{tabular}{c|c|c}
\hline No. & $\begin{array}{c}\text { Type of tourist } \\
\text { activities }\end{array}$ & Applied function \\
\hline 1 & $\begin{array}{c}\text { Mountaineering \& Rock } \\
\text { climbing }\end{array}$ & $\begin{array}{c}\text { Areas with the slope of } 20 \% \text { and elevation } \\
\text { classes of higher than } 1800 \mathrm{~m}\end{array}$ \\
\hline 2 & Rock climbing & Areas with a slope of greater than $50 \%$ \\
\hline 3 & $\begin{array}{c}\text { Rock climbing and } \\
\text { watching natural } \\
\text { landscapes }\end{array}$ & $\begin{array}{c}\text { Areas with an elevation of } 800-2050 \mathrm{~m} \text { and a } \\
\text { slope of 20-70\% where there are wooldlands } \\
\text { with different classes }\end{array}$ \\
\hline 4 & Skiing and winter sports & $\begin{array}{c}\text { Areas with altitudes of over 2,300 m and a } \\
\text { slope of 20-70\% where there is a possibility of } \\
\text { accumulating snow for ski resort }\end{array}$ \\
\hline 5 & nature therapy & $\begin{array}{c}\text { Areas within a radius of 1,500 m from the } \\
\text { mineral springs as well as rivers with sandy } \\
\text { beaches }\end{array}$ \\
\hline 6 & Water sports and fishing & $\begin{array}{c}\text { Areas on the 1-km periphery, around the } \\
\text { lakeandaquatic surfaces such as dams as well } \\
\text { as the distance of 1500 m from the riverbeds }\end{array}$ \\
\hline 7 & Ecotourism & Areas with beautiful sceneries \\
\hline 8 & Hiking in steep terrain & $\begin{array}{c}\text { Areas with an attitude of over 1800m and a } \\
\text { slope of greater than 30\% }\end{array}$ \\
\hline 9 & Visiting historic & Areas situated at a distance of 500 m away \\
monuments & from the historic monuments (Mirzaei, 2009) \\
\hline
\end{tabular}

\section{RESULT AND DISCUSSION}

\subsection{Suitable zones for mountaineering, caving, and rock climbing}

The suitable zones for caving in the Ilam Province include the areas with the height of over $1,800 \mathrm{~m}$ and a slope of $20 \%$ to $70 \%$ where there are pristine and natural caves. Covering 3.8\% (75519 ha) of the entire area of the province, this zone embraces mountains Kabir Kouh, Manasht, Sivan Kouh, Ghalarang, Guachan, Dinar Kouh, and Ghalajeh (Ahmadi, 2009). These areas are located mainly in the central and southeastern province at the border between the cities of Abdanan and Dare Shahr, as well as in the northern and northwestern province parallel, to the main highlands and the boundary line of the Zagros. Figure 2demonstrats suitable zone for caving, rock climbing, and mountaineering: The upper right-side picture is Manasht Mountain situated in the northern Ilam. The mountain is one of the richest wildlife habitats in the province, even in Iran, which has the height of 2,629 m above sea level. In the bottom right photo, Varzin Peak is illustrated as the tallest point of Kabir Kouh Mountain as well as the highest point in the province. This mountain range extends as a great wall to the length of $240 \mathrm{~km}$ playing an important role in plant and animal life of the Ilam Province. A large part of the area has high 
potential to rock climbing sport. This zone contains a large number of the county's well-known caves, one of which is Agha Cave has not been explored yet.

Figure 2- Suitable zone for caving, rock climbing, and mountaineering.

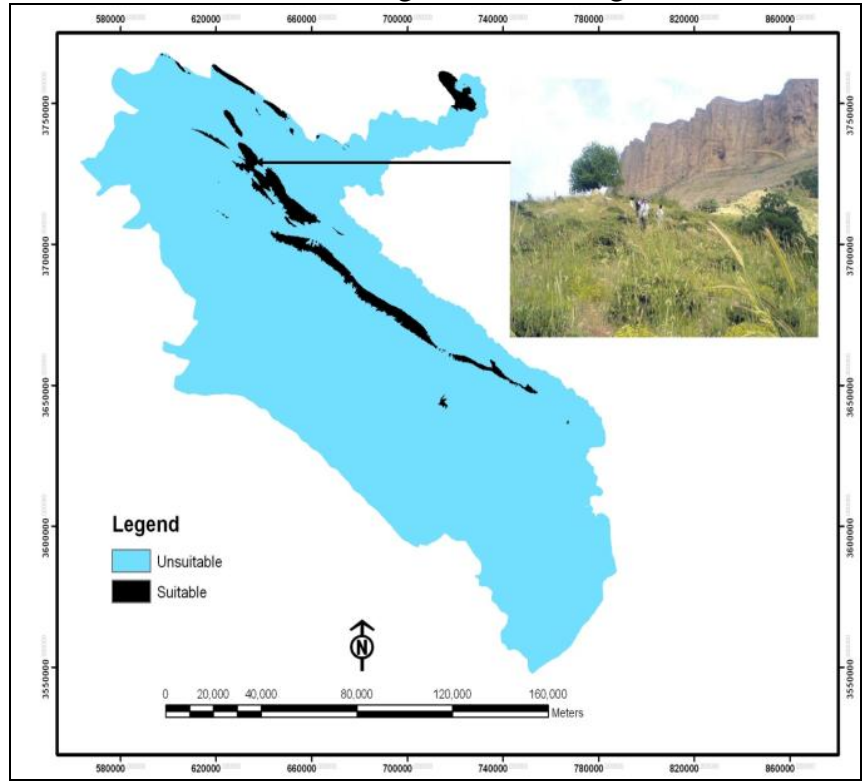

\subsection{Suitable zones for hillside climbing and visiting natural landscapes}

This zone includes $10.3 \%$ (189463 ha) of the total area of the province. The height of more than $800 \mathrm{~m}$ and less than $2050 \mathrm{~m}$ and the slope ranges between $20 \%$ to $70 \%$ are the most important constraints in this zone so as only 46\%(92731 ha) of the province is suitable for hillside climbing. The average annual temperature of the zone varies between $12{ }^{\circ} \mathrm{C}$ to $20^{\circ} \mathrm{C}$. The rainfall ranges between $400 \mathrm{~mm}$ to 900 $\mathrm{mm}$. Around $80 \%$ (151570 ha) of these hillsides are covered by woodlands, mainly extending in northern and central province. These areas have the greatest amount of rainfall in the province. The oak forests, beautiful rivers, and different pasture types offer unique sceneries to the visitors. These areas do not include the height of over $2050 \mathrm{~m}$ (in northern and central highlands) as well as gentle slopes and flat places in southern and border areas where are poor in terms of rainfall and land cover. Figure 3 depicts suitable zones for hillside climbing and visiting natural landscapes. The picture on the right shows the famous Arghavan Strait located at a distance of 3 $\mathrm{km}$ from the Ilam City. This zone is one of the most suitable herbal habitats in the province. It is also considered as one of the Iran's redbud species habitats. In fact,one of the densest oak forest reservoirs in the province and even in the country is located in this zone. 
Figure 3- Suitable zones for hillside climbing and visiting natural landscapes

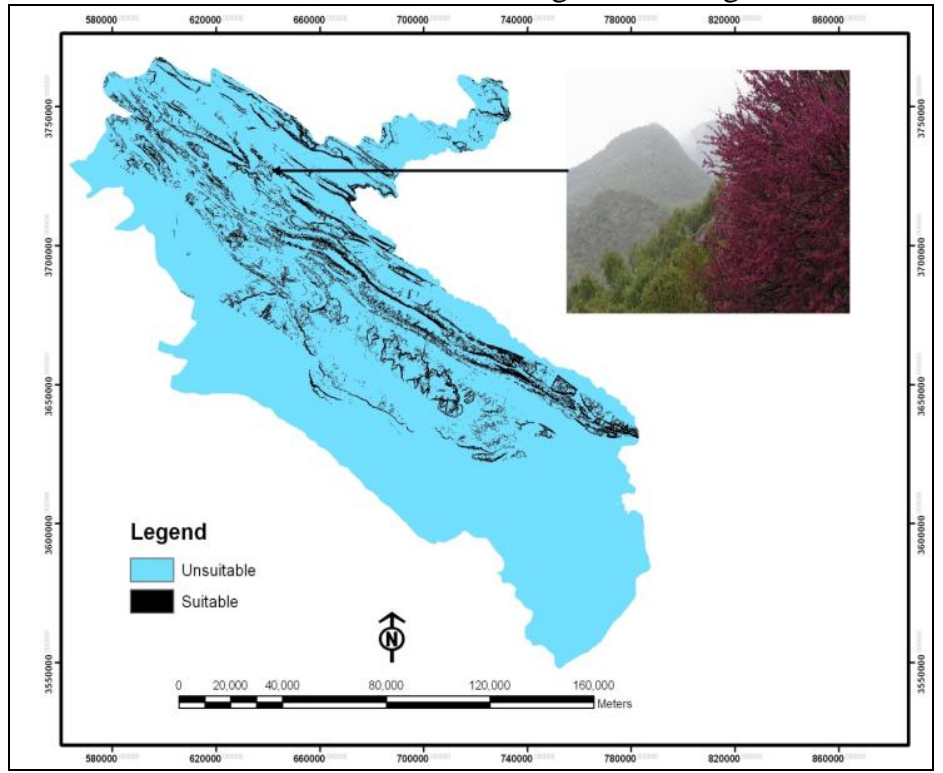

\subsection{Suitable zones for ecotourism and individual or family camping}

The suitable zone for ecotourism includes areas with beautiful sceneries. This zone covers $37.3 \%$ (592808 ha) of the entire study area. Having dense and semidense oak forest and permanent springs and streams, these areas can be a good place for ecotourism (Ahmadi, 2011) that mainly distributed in the northern province. these areas include Dalahou Forest Resort, Arghavan, Bankoul, Nam Tang, Tang Ghir, Dare Kalam, Tang Kafouri Resort, Tang Hianan, Khoran, Shesh Kalan, Mishkhas, the watershed of the Ilam Dam, and Dinar Mountain. The zone has the vastes area in the Counties Ilam, Ivan, Shirvan Chardavel, and Dare Shahr. and The zone has the highest rate of precipitation $(864 \mathrm{~mm}$ in Chenarbashi and $750 \mathrm{~mm}$ in the hillsides of Sharezoul) due to the high altitude and western winds. Rare and unique plant and animal species in some areas (Manasht, Bankoul, Sheshkalan, and Kolam), beautiful natural landscapes, tectonic forms, karst land forms, diverse plant species (Mozaffarian, 2005), and pleasant climatological conditions provide the most suitable recreational zones in the county. Figure 4presents suitable zones for ecotourism and individual or family camping: The top right photo shows the recreation area of Bankoul in the Northern Province and the photo on the bottom depicts the recreation area of Malle Panjab as one of the most well-known resorts in the province. 
Figure 4- Suitable zones for ecotourism and individual or family camping

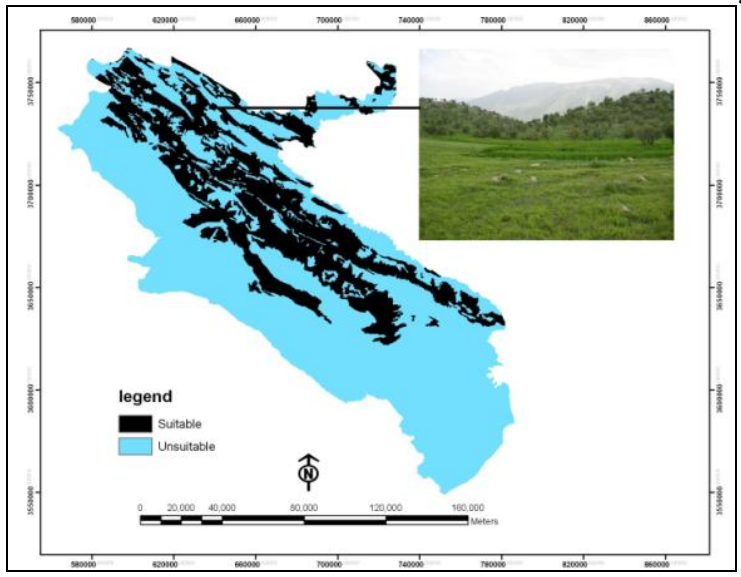

\subsection{Suitable zones for water sports, swimming, and fishing}

This zone is scattered in many different places, including around $12.4 \%$ (280703 ha )of the entire area of the province. The River Samireh, the longest river in the province, Kangir River, Siah Gav Wetland, the water basin of the Dams Ilam, and Ranguvan are among important water sport resorts. These areas include mainly the $1500 \mathrm{~m}$-periphery of the major rivers and springs. Figure 5 shows suitable zones for water sports, swimming, and fishing. The top right photo shows the artificial lake of the Ilam Dam while the bottom photo is one of the most amazing natural aquariums of Iran situated at the distance of $140 \mathrm{~km}$ far from the Ilam City resulted from the karst water discharge of Kabir Kouh Mountain. The aquarium has a depth of $30 \mathrm{~m}$ and the total area of both wetlands is less than 1 ha. This zone has been selected as one of the international target resorts.

Figure 5- Suitable zones for water sports, swimming, and fishing

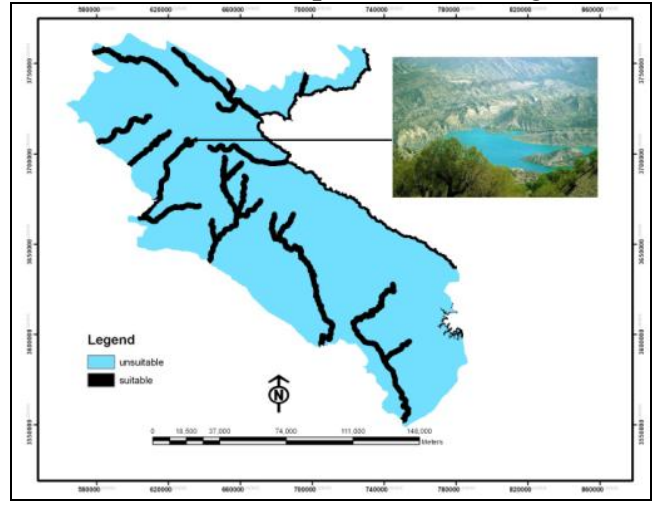

Bol. Ciênc. Geod., sec. Artigos, Curitiba, v. 21, nº 1, p.107-125, jan-mar, 2015. 


\subsection{Suitable zones for hunting}

In these areas, fishing and hunting must be done with the permission and under certain conditions. This zone does not include the protected areas of Manasht and Gholarang in the western province. As mentioned earlier, it is not allowed to hunt in other areas of the province unless observation of the necessary conditions. This is to prevent poaching. This zone includes large parts of the province. Figure 6 illustrats suitable zones for controled hunting: The picture on the right is one of the Ilam's animal habitats. The hunting and fishing is done in this zone under specific conditions in the anticipated seasons. The limitation is severe in hunting of mammals due to a sharp decline in their numbers in recent years.

Figure 6- Suitable zones for controled hunting

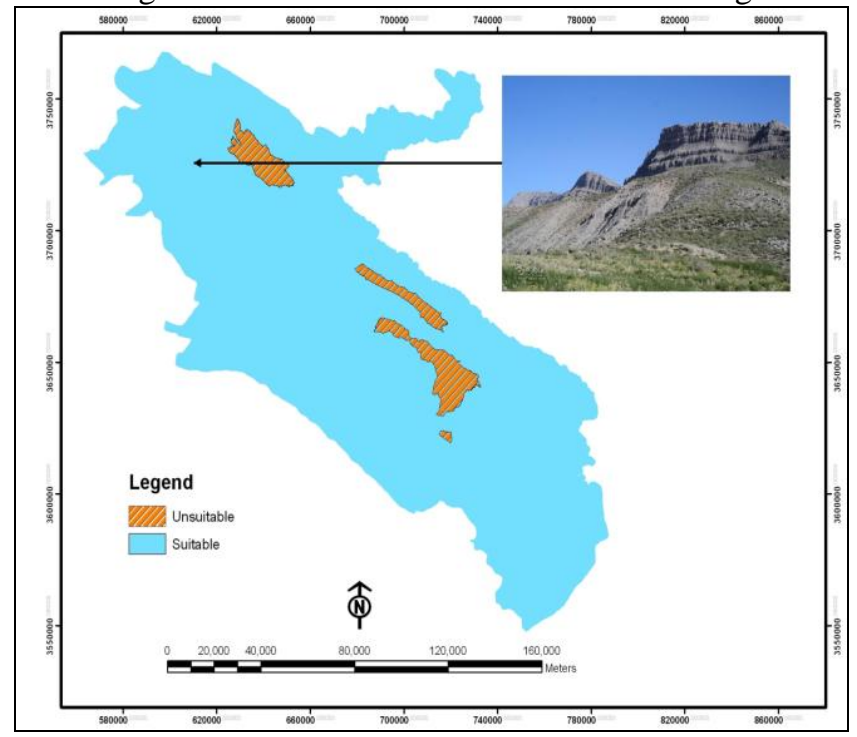

\subsection{Suitable zones for visiting historical monuments}

This zone covers historical places including Tange Ghir and Shams, presenting a combination of pristine natural landscapes and historical monuments. Among the historical target resorts in the province can be pointed to the Villages Sarabkalan, Zanjire Olia, and Sarab Kalam as well as Madakto Historical City and fringe areas of Abdanan. The beautiful natural landscape with historical monuments makes the area among foremost tourism resorts. This zone consists $0.6 \%$ (13282 ha) of the total area of the province. Figure 7 shows suitable zones for visiting historical monuments: The photo on the right is Madakto Ancient City dating to the fifth century BC. 
Figure 7- Suitable zones for visiting historical monuments

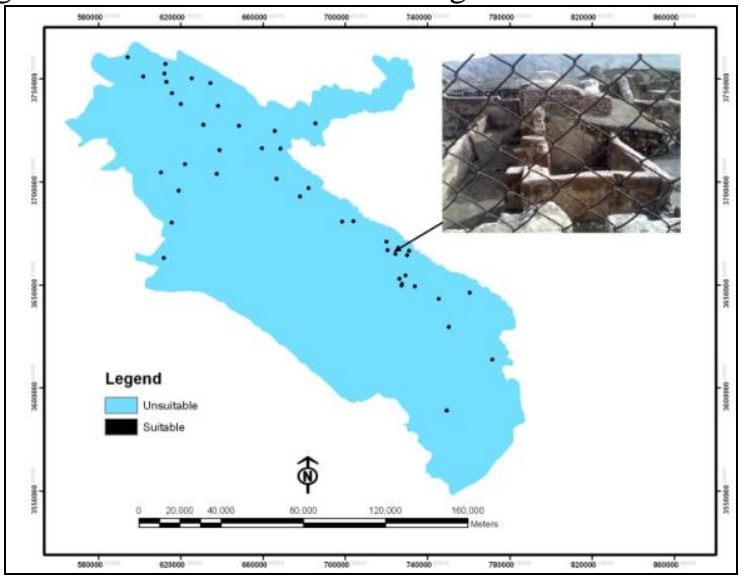

\subsection{Suitable zone for nature therapy}

This zone includes areas in adjacent to the mineral springs. Covering approximately $0.1 \%$ (710 ha) of total area of the province, these areas are situated in Dehloran County (Dehloran Hot Spring, $3 \mathrm{Km}$ away from the Dehloran County), Ilam County (Tang Bichar Hot Spring), and Dashtlag Hot Spring. Sulphurous hot springs with healing properties are located at a distance of $3 \mathrm{~km}$ from the Dehloran County, at the hillside of Siahkouh Mountain and in the vicinity of the Khofash (semantically equivalent to bat) Cave. With an approximate temperature of $50{ }^{\circ} \mathrm{C}$, it contains hot springs and sludge therapy pools that are of particular health care importance. This is a very effective healing source for rheumatism, allergies, wounds, broken bones, and bruises (Figure 8).

Figure 8- Suitable zone for nature therapy: The photo on the right illustrates the

Dehloran Hot Spring

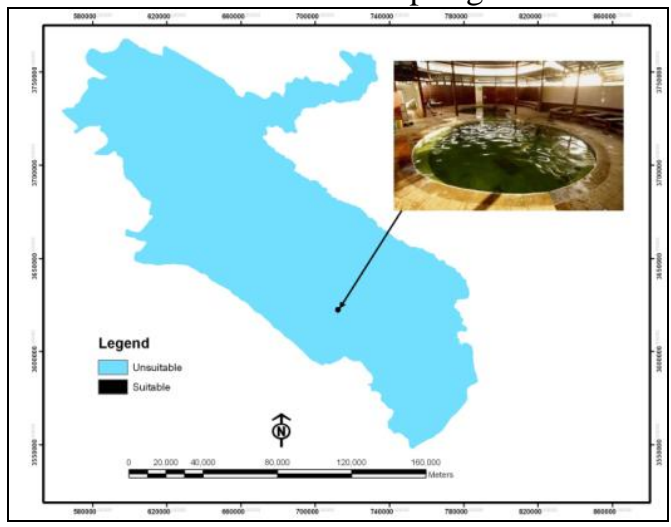

Bol. Ciênc. Geod., sec. Artigos, Curitiba, v. 21, nº 1, p.107-125, jan-mar, 2015. 


\subsection{Suitable zones for winter sports}

The Ilam Province has high and dense mountains. The mountains with an altitude of over $3000 \mathrm{~m}$ are rarely observed in the province so that the mountains higher than $2000 \mathrm{~m}$ include less than $2 \%$ ( $8087 \mathrm{ha}$ ) of the total area of the province. There are few mountains in the province with the altitude of higher than $2600 \mathrm{~m}$. Heavy snow showers in winter (more than $400 \mathrm{~mm}$ ) have created a thick layer of snow on the mountains. The suitable areas for winter sports constitute around $1.51 \%$ (8087 ha)of the total area of the province. Figure 9 gives suitable zone for winter sport. The photo on the right is one of the Kabir Mountain's peaks where is suitable for winter sports. The height of the top of the peak is 9 thousand feet where the rainfall exceeds $1000 \mathrm{~mm}$ per year. Heavy precipitations in winter provide that certain conditions for winter sports.

Figure 9- Suitable zone for winter sport

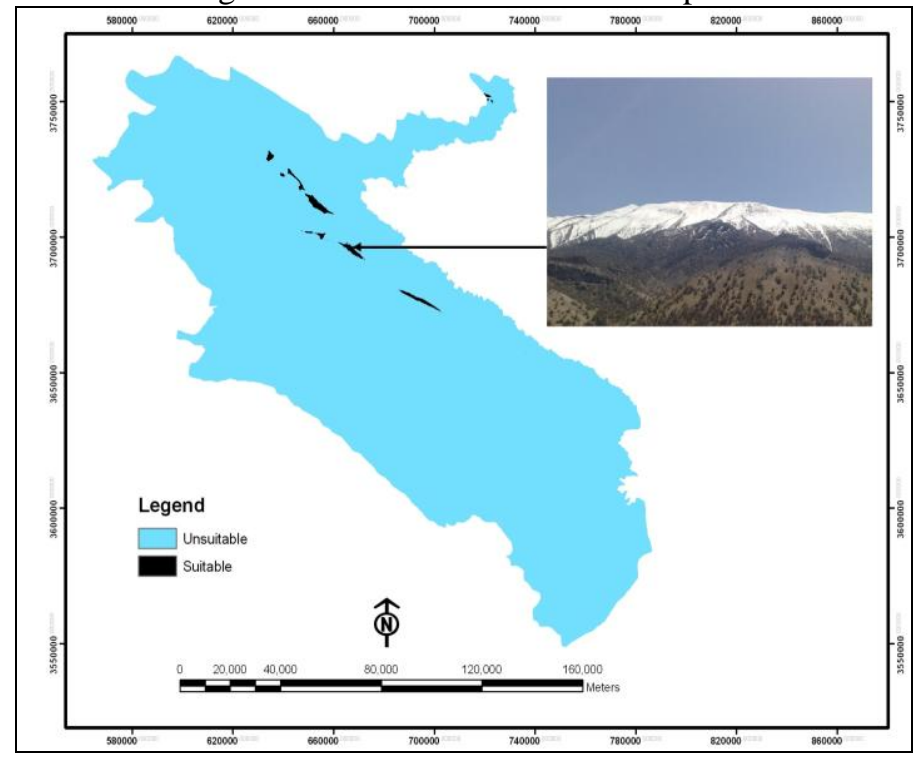

\subsection{Final ecotourism zoning map}

After overlaying the map layers using the Boolean model, the ecotourism land capability map was prepared. According to which, the Ilam Province is divided into small zones of $0,1,2,3$, and 4 (Figure 10). 
Figure 10- Final map of suitable zones for ecotourism planning in the Ilam Province based on the Boolean logic

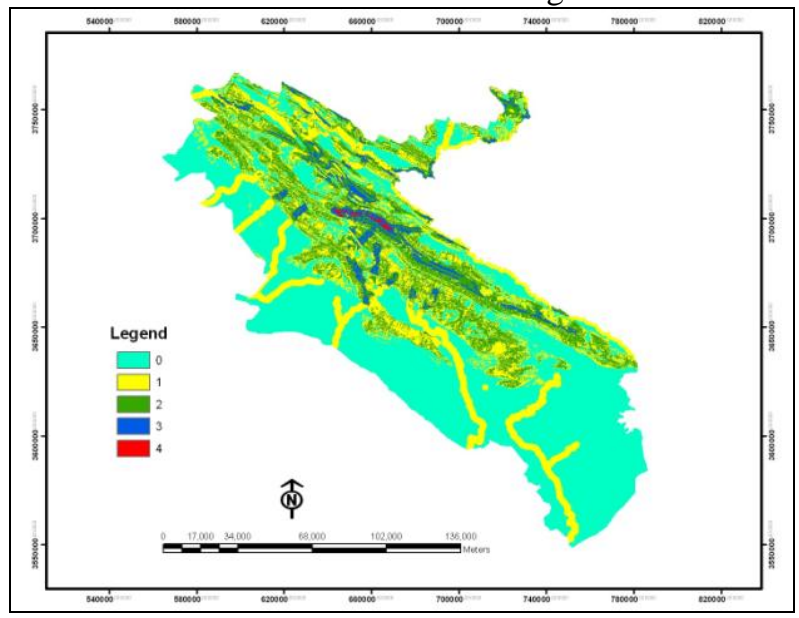

The zone No. 0: this zone has no potential for ecotourism developement. It includes $47 \%$ (1029652 ha) of the total area of the province. Homogeneous terrain in the southern and border areas creates a uniform landscape in the Zone 0 . Accordingly, gentle slopes and the altitude of less than $800 \mathrm{~m}$, the zone has no potential to establish any of the tourism activities listed exept for the areas in the periphery of the rivers and the Dehloran Hot Spring,.

Zone No. 1: this zone has the required potential for just one ecotourism activity. Including more than 26\%(520612 ha) of the entire area, this zone has the largest extent in the province. It covers southern and border areas, the $1500 \mathrm{~m}$ periphery of the Rivers Doyraj, Meymeh, Gavi, and Changouleh. This zone can be seen in the southern province as a yellow spot including the Dehloran Hot Spring. The hillside climbing and water sports are among the tourism resorts of the zone.

Zone No. 2: this zone is mainly scattered in the central and Northern Province where the required potentials for the hillside claiming and ecotourism are provided and forest land cover reaches its greatest extent. The altitude of this zone ranges between $800 \mathrm{~m}$ to $2000 \mathrm{~m}$ and the rainfall varies from $400 \mathrm{~mm}$ to $800 \mathrm{~mm}$. Constituting 17\% (341325 ha)of the total area, this zone is seen as spots in other parts of the province.

Zone No. 3: As a long string, this zone is stretched from the northern to the central and southeastern province. It is situated in the hillside of the Kabir Mountain as well as the high mountains in the north with potentials for the ecotourism activities including mountaineering, caving, visiting natural landscapes, winter sports, and camping. The dense and semi-dense woodlands cover around 90\% 
(58842 ha)of the zone. As the most suitable area for rock climbing sport, this zone is one of the pristine areas of the province including lush green slopes of the high mountains. It is among the rainiest regions of the province covered by oak forest with dense and semi-dense canopy and bulk volume rocks. Around 3.6\% (65392 ha) of the total area of the zone is allocated to the zone 3.

Zone No. 4: this zone is usually observed as red spots throughout the central province where the highest elevation is $3062 \mathrm{~m}$ (Varzing) and the maximum precipitation is $863 \mathrm{~mm}$ (in Chenarbashi Village). Having a wilderness landscape, this zone has the required potential for the ecotourism activities including mountaineering, hillside climbing, visiting natural landscapes, ecotourism, and winter sports. This zone has the highest potential for ecotourism development compared to other areas. Although the Ilam Province, with an area of $20000 \mathrm{~km}^{2}$, is considered as one of the smallest provinces of Iran, however, it has an incredible diversity of climatic and pedologic situations. It is a few kilometers away from the snow-capped mountains and includes warm plains, and the old oak and palm trees. In general, the different highlands compose the landscape of the Ilam Province. The mountain landscape with forested valleys is created one of the most beautiful natural landscapes in the region (Figure 10).

\section{CONCLUSION}

The results obtained from data analysis revealed that around 53\%(1029652 ha) of the total area of the Ilam Province has the required potential for ecotourism activities such as mountaineering, caving, hillside climbing, nature therapy, winter sports, etc. In this study, the map layers including elevation, slope, land cover, hydrology and so on were overlaid using Boolean logic to determine land capability of the province for different ecotourism activities. According to the results, the ecotourism with the total area of more than 30\% (592808 ha) allocates itself the maximum extent. This is due to rich land cover and forest areas of the province so that woodland and rangeland areas cover 30\% (619179 ha) and 80\% (1634634 ha) of the total area of the province, respectively. The second top priority tourism activity is hillside climbing due to high density of mountain areas covered by wilderness land cover in an area of $10.7 \%(186463 \mathrm{ha})$ with gentle slopes. The nature therapy with an area of less than $0.1 \%$ (710 ha ) has the smallest extent in the study area. It is worth nothing that these zones were identified based on the rigorous approach of Boolean logic and it does not mean that other areas have a poor recreational potential. The other parts could also be evaluated from other points of view. What has been investigated in this research is to zone and introduce suitable sites in the form of an ecotourism map which can be used as a workplan for ecotourism development in the study area.

\section{ACKNOWLEDGEMENT}

The authors would like to express their sincere appreciation to the proofreading services rendered by Ravian Danesh Mohit Company. 


\section{REFERENCES}

AHMADI, M., identify areas suitable for geotourism development in Ilam province using GIS. Master's thesis. kharazmi University, 2009.

AHMADI, M. identify areas suitable for ecotourism development in the darecahrr township using AHP model . International Conference on Tourism and Sustainable Development, Tehran, 2011.

AMAMI MEYBODI, A. Principles of Performance Measurement and Productivity Institute. Business Research,2000.

BARAL, B.; STERNB, M. J.; BHATTARAI ,R. Contingent valuation of ecotourism in Annapurna conservation area, Nepal: Implications for sustainable park finance and local development.

ALPET, P. Integrated conservation and development projects. Bioscience, 46, P. 845-855, 1996.

BANSAL, P. D.; ARNOLD. J.; ELBERG, M. A.; KALDA, J.; SOESOO, A.; VAN MILLIGEN, B. P., "Melt extraction and accumulation from partially moltern rocks", Lithos ,78, 25, 2004.

BANERJEE,U.K.S.; KUMARI, S.K.P.; SUDHAKAR, Remote Sensing and GIS based ecotourism planning :A case study for westrern Mindnapore, West Bengal India, 2002.

BOO, E. "Ecotourism: The potentials and pitfalls", Washington, DC, World Wildlife Fund: 21-33, 1990.

BOYD, S.W.; BUTLER, R.W.L; HAIDER, W.; PERERA, A. Identifying areas for ecotourism in northern Ontario: application of a geographic information system methodology. Journal of Applied Recreation Research,19 ,P.41-66, 1994.

BRANDON, K. Ecotourism and conservation: A review of key issues. Washington, DC: World Bank. 1996.

BRANDON, K. Moving beyond Integrated Conservation and Development Projects (ICDPs) to achieve biodiversity conservation. In D. R. Lee, \& C. B. Barrett (Eds.), Tradeoffs or synergies?Agricultural intensification, economic development and the environment. New York, NY: CABI Publishing. pp. P.417-432, 2001.

BUKENYA; JAMES, O. Application of GIS in ecotourism development descisions :evidence from the pearl of Africa, natural resource economics program, west Virginia university - Morgantown,wv,2,P.6506-6108, 2002.

CATER, E. Ecotourism in the third world: problems andprospects for sustainability. In E. Cater, \& G. Lowman (Eds.),Ecotourism: A sustainable option? Chichester: Wiley, pp. 69-86,1994.

CEBALLOS-LASCURAIN, H. Ecotourism as a worldwide phenomenon. In K. Lindberg, \& D. Hawkins (Eds.), Ecotourism: A guide for planners and managers, p. 12-14, 1993. 
CEBALLOS-LASCURAIN, H. Introduction. In K. Lindberg, M. E. Wood, \& D. Engeldrum (Eds.), Ecotourism: A guide for planners and managers, pp. 7-10, 1998.

CHANGA, K.F.; C.M.; CHIANBG, P.C. Chouc, Adapting aspects of GB Tool 200 - searching for suitability in Taiwan, Building and Environment,42, P.310-316, 2007.

LEE CH. K.; SONG H..J.; Mjelde J.W. the forecasting of international Expo tourism using guantitative and gualitative techniques.tourism management,29,P.1054-1098, 2008.

COOKE, K. Guidelines for socially appropriate tourism developmentin British Columbia. Journal of Travel Research, 21, P.22-28,1982.

DYE, A.S.; LUNG SHAW, SH. A GIS-based spatial decision support system for tourists of Great Smoky Mountains National Park. Journal of Retailing and Consumer Services, 14, P.269-278, 2007.

DONDO, CH.; BHUNU, S.T.; Rivertt, U. GIS in tourism - A Zimbabwean perspective, the international archives of photogrammetry, remote sensing and spatial information sciences, vol .xxx IV, part 6/w6. 2003.

EGOH, B.; REYERS, B.; ROUGET, M.; RICHARDSON, D.M.; LE MAITRE, D.C.; VAN JAARSVELD, A.S. Mapping ecosystem services for planning and management. Agriculture, Ecosystems and Environment ,127, P.135$140,2008$.

ELLIOTT-WHITE, M.P.; FINN, M. Growing in sophistication: the application of geographic information systems in post-modern tourism marketing. Journal of Travel and Tourism Marketing ,7 ,P.65-84, 1997.

Encyclopedia of Ilam city. Armed Forces Geographical Organisation Publishing. Tehran, Iran. 2008.

FARAJ ZADEH, M. Analysis zones for ecotourism development in Kurdistan province using GIS, Journal of Geographical research, 2008.

GUO, Z.W.; XIAO, X.M.; GAN, Y.L.; ZHENG, Y.J. Ecosystem functions, services and their values - a case studies in Xingshan County of China. Ecological Economics ,38, P.141-154, 2001.

FENNEL. A. D. "Ecotourism an Introduction" Routledge, p. 315,1999.

HALL, G.B.; WANG F.; SUBARYONO, S. Comparison of Boolean and fuzzy classification methods in land suitability analysis by using geographical information systems. Environment and Planning, A. 24, P.497-516, 1992.

HEIDARI, S.; BEIGI, M..; MOHAMMADI, S. Anthropology of Tourism , Tourism Master Plan ,university of Ilam. 2003.

HEIN, L.; VAN KOPPEN, K.; DE GROOT, R.S.; VAN IERLANDE, E.C. Spatial scales, stakeholders and the valuation of ecosystem services. Ecological Economics ,57,P. 209-228. 2006.

HETZER, N. D. Environment, Tourism, Culture", links(July), Reprinted in Ecosphere: P.141-158,1965. 
HONEY, M. Ecotourism and Sustainable Development, Who Owns Paradise? (Second ed.), Washington Dc., Island Pres, 2008.

HOWARD,W.R. Risky business? Asking tourists what hazards they actually encountered in Thailand: Tourism Management: 30, P.359-365, 2009.

HUNTER, C. Sustainable tourism as an adaptive paradigm. Annals of Tourism Research, 24, P.850-867. 1997.

JAFREE, G. studies of Environmental Tourism, Ilam University, 2003.

JOHARI, G. Evaluation of tourist places in Ilam, Ilam University, 2005.

JIANG, J. Evaluation of the Potential of Ecotourism to the Contribute to Local Sustainable Development: A Case Study of Tengtou Village, China, Massey University, New Zealand,2008.

LAUGHLAND, A.S.; MUSSER, W.N.; SHORTLE, J.S.; MUSSER, L.M. Construct validity of averting cost measures of environmentalbenefits. Land Economics 72 ,P. 100-112, 1996.

LEE, C.K.; MJELDE, G.W. Valuation of ecotourism resources using a contingent valuation method: The case of the Korean DMZ, ECOLOGICAL ECONOMICS, 63 ,P. 511 - 520, 2012.

MILLER, G. The development of indicators for sustainable tourism: results of a Delphi survey of tourism researchers. Tourism Management, 22,P. 351-362, 2001.

MOZAFFARIAN, V. four new species of plant knowledge of Ilam province of Iran, Journal of Botany, 87,P. 28-94, 2005.

OLAZADE, A. of Process Evalvation Physical Development and Determination of Optimal Directions for Future Development in Saqez Using GIS, MS Thesis, the Guidance of Gholamali Mozafari, Department of Geography, Yazd University, 2005.

ROSS, S.; WALL. G. Evaluating ecotourism: The caseof North Sulawasi, Indonesia. Tourism Management, 20, P.673-682, 1999.

SANAEI NEJAD, S.H.; FARAJI SABOKBAR, H. A. GIS Applying GIS in Urban and Regional Planning, Second Edition, Ferdowsi University Press, Mashhad. (in Persian), 1999.

SANJAY, P.H.; NEPAL, K.. Local perspectives of ecotourism development in Tawushan Nature Reserve, Taiwan, Tourism Management ,27 ,P. 11171129,2006

SAVITSKY, B.; ALLEN, J.; BACKMAN, K.F. The role of geographic. information system (GIS) in tourism planning and rural economic development. Tourism Analysis ,4 ,P. 187-199, 1999.

STUEVE, A.; COOK, D.S.;DAWN, D. the Geotourism study phase I Executive Summary.The Research Departemant of the Travel Industry Association of America Washington, D.C, 2002.

TREMBLAY, P. Desert Tourism Scoping Study, Desert Knowledge CRC, Report 12, Australia, Charles Darwin University, 2006. 
TROY, A.; WILSON,M.A. Mapping ecosystemservices: practical challenges and opportunities in linking GIS and value transfer. Ecological Economics ,60 ,P. 435-449, 2006

TURNER, R.K.; FOLKE, C.; GREN, I.M.; BATEMAN, I.J. Wetland valuation: three case studies. In: Perrings, C., Maler, K.-G., Folke, C., Holling, C.S., Jansson, B.O. (Eds.), Biodiversity loss: economic and ecological issues. Cambridge University Press, Cambridge, MA, USA,1995.

WELLS, M.P.; BRANDON, K. E. People and parks: Linking protected area management with local communities. Washington, DC: World Bank, 1992.

WIGHT, P. A. Environmental sustainable marketing of tourism.In E. Cater, \& G. Lowman (Eds.), Ecotourism: A sustainable option?, Brisbane, Wiley, pp39$56,1994$.

YOON, Y.; GURSOY, D.; CHEN, J. S. Validating a tourismdevelopment theory with structural equation modeling. Tourism Management, 22,P. 363-372, 2001.

(Recebido em junho de 2014. Aceito em novembro de 2014). 